Aleksandra S. Dragin ${ }^{1}$

UDK 338.48:656.62>(497.11)

Dobrica Jovičić ${ }^{2}$

Review

Desimir Bošković ${ }^{3}$

Pregledni rad

\title{
ECONOMIC IMPACT OF CRUISE TOURISM ALONG THE PAN- EUROPEAN CORRIDOR VII
}

\begin{abstract}
This paper provides some tentative estimates of the economic impact of cruise tourism in receptive countries and regions along the Pan-European Corridor VII. Examples are provided to illustrate the potential benefit to Vojvodina Region (Case study).

The results of the analysis have shown that the Corridor VII cruises have positive impact on Vojvodina Province, primarily the riparian area of the Danube (only Novi Sad - the "Port of Vojvodina for cruisers"). Although the benefits exclude accommodation and food expenditure, they are noticeable within the following segments: tourism promotion (broadening the scopes of Vojvodina Province as a receptive area for the foreign market through its cultural heritage and natural values); increase in foreign tourist turnover, visitor's expenditures; new job opportunities (adequate infrastructure and superstructure - rendering services to ships, crew and passengers) - harbors, carriers, souvenir shops, etc. / new products, business net, exchange money, invisible export, etc.

The results of the research may initiate further studies on the cause and effect connections between this type of travelling and resources of receptive countries, upon which the travels are based, both aiming at adequate design and launching of the tourist offer, i.e. the optimal development of receptive countries through sustainable tourism. Also, the discussion provides potentially useful information to the different stakeholders in the evolving cruise tourism industry, particularly regarding expected (private or social) returns on investment.
\end{abstract}

Key words: tourism, cruise, the Danube, Vojvodina Region, Serbia, transition, economic impact, demography.

\section{INTRODUCTION}

Cruising is becoming a more and more popular segment of tourism (Gibson, 2006; Hobson, 1993; Peisley, 1992, 2006). According to the Cruise Lines International Association (CLIA) (CLIA, 2006a; CLIA, 2006b), the industry has experienced an average annual growth of $8.2 \%$ since 1980 . This is double the long-term average growth figure of $4.1 \%$ for tourism in general (World Tourism Organisation, 2006). According to what other sources claim, cruisers are one of the leading areas of international tourism regarding the speed of development and the increase in demand - of the realised tourist flow (CLIA, 1992, 1995; Hobson, 1993). The demand for cruisers increased by 50\% in the period between 1989 and 1996, and the same trend continued in the period between 1996 and 2000 (World Tourism Organization, 2003). In 1995 there were about 5.7 million tourists cruising the world. In 2000, there were about 9.6 million (Dowling, 2006), and in 2004 about 14.3 million tourists. In the first half of 2005, CLIA explained the phenomenon of global expansion of cruisers by using

\footnotetext{
${ }^{1}$ Assistant professor, University of Novi Sad, Faculty of Science, Department for Geography, Tourism and Hotel Management, Trg Dositeja Obradovica 3, 21000 Novi Sad, Serbia; aleksandra.dragin@dgt.uns.ac.rs

${ }^{2}$ Associate professor, University of Belgrade, Geographical Faculty, Department for Tourism, Studentski trg 3, 11000 Belgrade, Serbia; dobricaj@eunet.rs

3 desimir.boskovic@pu.t-com.hr
} 
data referring to 2004, when about 30 million Americans showed interest in participating in cruising in the following three years, which could not have even remotely been predicted in 1975, when the Association was founded (CLIA, 2005a).

If we take a single bed as a parameter for the basic unit of accommodation capacity, cruisers include $0.6 \%$ of the total accommodation capacity in the world (World Tourism Organization, 2003, taken from Dowling, 2006). It is interesting to note that cruisers reached $104 \%$ of capacity utilisation, despite the fact that in 2000 the fleet of this kind of ships at global level increased by 62 new cruisers (CLIA, 2005b). It was predicted that in 2006 tourist flow will rise to 15 million tourists and in 2012, 20 million tourists on cruisers are expected (Cruise Information Service, 2005). These expectations were surpassed, at least if we take 2006 into account, with the total of 16 million registered tourists (Dowling, 2006). The same source notes that cruisers worldwide tend to reach the overall number of about 19 million tourists in 2010, which would represent the rise of $70 \%$ compared to the year 2000 . This means that the number of passengers will be four times higher in the period of four years. The reasons for this are bigger ships (greater accommodation capacity / the concept of resort), as well as the increase in average age of population worldwide, apart from Asia (Dowling, 2006).

Besides the primary goal (travelling), there are many objects of nautical infrastructure included, as well as complementary products and services in the function of tourism (piers, jetties, accommodation, food, culture, entertainment, sports, recreation) (Dowling, 2006; Ivkov et al., 2007; Ward, 2005). The development of nautical tourism at a national level is by all means determined by the quality of the cruiser offer, and is further reflected onto the country's economic benefit from nautical tourism (Dragin, 2008; Dwyer, Forsyth, 1998; Dragin, Ivkov, Dragin, V; 2006).

Previously published works on cruise tourism mainly deal with the problems from the fields of sociology, i.e. anthropology and economy. The economic impact and benefits of the cruising tourism has been researched by a number of authors (Braun, Xander \& White, 2002; Brida, Aguire, 2008; Chase, Alon, 2002; Dragin, 2010; Dwyer, Forsyth 1996; Foster, 1986; Hall, Braithwaite, 1990; Henthorne, 2000; Hobson, 1993; Mescon, Vosikis, 1985, Mancini, 2000). All studies concern cruising refer to trans-ocean cruises. It is rather difficult to find a research that covers the cruises along European receptive areas, especially on rivers which are becoming more and more popular way of spending free time. Moreover, almost all the published studies that deal with cruising treat tourists as their main object of interest (e.g. Armenski, Zakić \& Dragin, 2009; Dowling, 2006; Hung, Petrick, 2010; Li, 2006; Petrick, 2003; Petrick, 2004; Petrick, Sirakaya, 2004).

\section{RIVER CRUISERS}

In 2003, river cruisers reached the overall number of tourists visiting of 1.3 million, which is about an $11 \%$-rise compared to the previous year. In the development of global tourism, the Danube became a significant tourist route, which is evident in the data (Serbian Ministry of Commerce, Tourism and Services, Horwath Consulting Zagreb and the Faculty of Economics Belgrade (MHCEF), 2005) that in 2003 there were 392,766 tourists cruising the Danube (followed by the Nile with 266,978 and the Yangtze with 151,459 tourists). This tendency on the market of river cruisers is the result of high life standard of the population in certain countries (Northern, Western and central Europe and the USA), greater competition between the ships with lower prices of tourist services (e.g. ships from Russia, Ukraine, Bulgaria), segmentation of the tourist demand and supply aiming to discover new tourist activities, requirement for a safe journey (Dragin, Ivkov \& Dragin, 2006). Tourist recreation 
has become available to a greater number of people and it has found its role in their philosophy of life.

The greatest increase of the tourist flow of cruisers is expected in new European destinations - generating route of nautical tourism (Hungary, Romania, Slovakia, Croatia and Serbia), mostly in the Danube countries - Corridor VII. Corridor VII is defined by the European Agreement on Main Inland Waterways of International Importance. Corridor VII is the Danube river with the system of natural and artificial waterways: the Danube (E 80), canal Black Sea - Danube (between Chernovoda and Constantia) (E 80-14), arms Chilia (E 80-09) and Sulina, the Tisza in Serbia and Hungary, the Vah in Slovakia, canal Danube - Sava (E 8010), canal Danube - Odra - Elba (in Austria, the Czech Republic, Germany and Poland) and relevant port infrastructure (www.tinavienna.at/service/upload/MoU.pdf).

\section{THE IMPACT OF CRUISE SHIP TOURISM IN LOCAL ECONOMY}

The cruises along the Corridor VII are characterised by complexity, i.e. multiplicity, which is the result of the fact that they are the object of interest and demand of tourists from a great number of countries in Central and Southeast Europe. Each one of them presupposes specific conditions of the offer and organisation as well as specific strategy of the cruisetourism development (Dragin et al., 2007; Dragin, Đurđev \& Armenski, 2008). The key generating markets of this kind of tourism are the USA, Germany, France, Great Britain and Austria (Dragin, 2010).

The aim of the paper is to explore the potential benefits for the receptive countries and regions (Case study: Vojvodina Province) by launching this tourist product to the world market. The results of the research may initiate further studies on the cause and effect connections between this type of travelling and resources of receptive countries, upon which the travels are based, both aiming at adequate design and launching of the tourist offer, i.e. the optimal development of receptive countries through sustainable tourism.

\section{SAMPLING AND METHODOLOGY}

Key countries in the itineraries are Austria, Slovakia, Hungary, Croatia, Serbia, Romania and Bulgaria. The programme as well includes border regions of Germany, Moldova and Ukraine. It is interesting that five European capitals are placed along the Corridor VII: Vienna, Bratislava, Budapest, Belgrade and Bucharest. The research consists of two segments:

Analysis of the contribution of the Corridor VII cruises to receptive region: The research used for this is a three-years field study (2007-2009). This was done by means of written data sources analysis, surveys, interviews with tour-operators, captains and crew, agencies, and forwarding agents. The analyses were done at following locations: ports and ships, travel agencies ("Putnik"), transportation companies ("Vojvodina" and "Putnik"), restaurants (MB "Rodic"), museums (the Museum of the City of Novi Sad), etc. (the research that is presented here is part of the project approved by the Ministry of Science of the Republic of Serbia (No. 146017d) and also a part of the doctoral dissertation defended by Aleksandra Dragin at the University of Novi Sad in 2008).

Analysis of customers: 151 tourists were interviewed in order to identify the motives underlying their selection of a tour along the Corridor VII (including the Vojvodina section) and to discuss their travelling experience and impressions (the attractiveness of the tour, their picture of Vojvodina before and after the trip, etc.). The research used for this is two-years field study (2007-2008) - methodology "paper, pencil and talk" (survey). The interviews with cruisers were done at "Port of Novi Sad 2". Survey on the quality of services during 
cruises along the Corridor VII was done in order to comprehend the manners in which tourists experience Vojvodina. A special attention was given to questions about the travel motives, experience gained during the travel, the most attractive elements of the supply in Novi Sad within international cruises along the Corridor VII, the opinion tourists had about Vojvodina Region before and after the visit, etc.

Since the countries along the Corridor VII do not have analysis of the subject, some data has been collected from the manifests of the cruises which docked in Novi Sad, Vojvodina (2,218 of employees have been included - crew from 54 cruisers) in 2007 (ninemonth field study - whole year season). The sample represents $10.4 \%$ of the total tourist flow in Novi Sad in 2007. The most widely represented cruisers are: "River Aria" (Grand Circle Travel Cruise Line, Worldwide RC Ruises), "Heinrich Heine" (Viking River Cruise), "Ms Johann Strauß" (Austrian River Cruises), "Maxima" (Phoenix Reisen Gmbh Bonn), "Ms Victor Hugo" (L'Europe en Croisières), "River Adagio" (Grand Circle Travel Cruise Line, Worldwide RC Ruises), "Beethoven" (L'Europe en Croisières), "River Navigator" (Deluxe World Travel Vantage), "Odyssey" (Deluxe World Travel Vantage), "Erasmus" (B.V. Scheepvaart MIJ.), "Ms Artistry” (Avalon Waterways), “Amadeus” (Lüftner Reisin Austria), etc.

The basic methods used while obtaining and processing data and analysing the results are: field research (systematically observation and questioning, i.e. crew and passenger interviewing), historical method (written documents, statistical data, research of the results from similar researches etc.), statistical procession of literature and other material, quantitative and qualitative content analyses, comparative method.

\section{DISCUSSION}

The Corridor VII cruises highlight the attractiveness of Danube, Tisza and Sava basins and numerous complementary tourist values of natural and anthropogenic content. The tourist offer design emerges as one of the most important activities of tourist product designers (leading American and European tour operators). The proper design of a tourist package requires a detailed study of the market (target groups research, "innovative" destinations, redesigning of the "old" tourist offer, etc.). Therefore, the designers of the tourist products, based on the Danube river, tend to provide dynamic and stable balance of offer and demand, by fine tuning of marketing mix basic instruments to market demands; what is more, to direct the demand towards the offer through tourist communication by means of homological and analogical codes.

Tourist season is the period from March to November. The market offers different arrangements by numerous tour operators, lasting from approximately ten days up to four weeks. Tour operators are mainly from the USA (Massachusetts) - "Grand Circle Travel" and "Vantage Deluxe World Travel", California - "Viking River Cruises), from Germany ("Peter Deilmann", "Phoenix Reisen Gmbh" and "Nicko Tours") and from France ("Croisi Europe") (Dragin, Bubalo-Živkovic, Ivanović, 2009).

Tour packages offers of the Corridor VII cruises comprise various activities, among which stand the airline transport, railroad routes between the cities in the itinerary, accommodation facilities on vessels and in hotels, exclusive trips (sightseeing of the towns, vine tours, visits to castles and art colonies, etc.), cultural, educational and artistic programmes, dinner with the ship captain, additional services (e.g. information desk on the ship, sports and recreational activities, optional visits), etc. Usual capacity of ships ranges between 100 - 120 tourists (from 48 to 180 tourists).

Passenger expenditure includes that incurred as part of the cruise (port visit expenditure) and also the payment for it. Thus it includes air fares to/from the base country - 
some of which will be paid to airlines owned by the country (Dwyer, Forsyth, 1996) (Figure 1). There are also travels within counties (by bus - in all counties along the Corridor VII and by train - in Romania).

\section{Figure 1.}

\section{Cruise Related Expenditures}

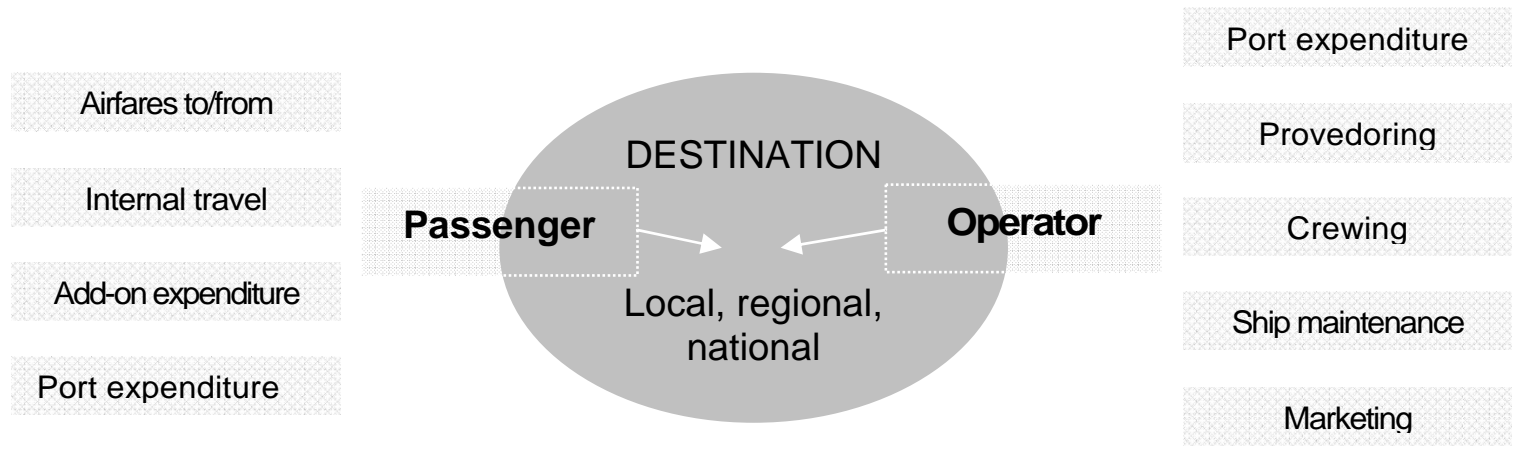

Sources: Dwyer, Forsyth, 1996; Dwyer, Forsyth, 1998

Some add-on expenditures (hotel accommodation, meals, tours \& attractions in port before or after cruising) are essential for the locals. In some counties along the Corridor VII (for example in Hungary, Croatia and Romania) there are possibilities for tourists to spent some days on lend before and after cruise (in Budapest, Dubrovnik and Bucharest). Visitors also make direct expenditures on excursions, attractions and shopping, while on the cruise (Dwyer, Forsyth, 1996).

The operators (tour operators) charter the vessels; whereas tourist agencies render services to the cruise tourists on land and charter the vessels' capacities to be included in their programmes. As we mentioned, the tour operators are foreign companies. Even if a payment for a cruise is made in the base country, using its currency, this does not feature as "expenditure in the base country", since it is income payable abroad, and does not stimulate economic activity within this country. Passenger expenditures include the cost of the cruise, but this is an amount paid to a foreign company, and it is not included (Dwyer, Forsyth, 1996; Figure 1).

On the other side, tour operators make a range of payments. They pay charges associated with the use of a port (to cover the cost of navigational services of government as well as for the terminal used). The operator will purchase goods and services to provision the vassel, including stores and provedoring, fuel, waste disposal, electricity etc. There are some expenditure also for the crew - in additional, the operator will hire foreign crew (some of them are from stopover ports). Apart from these, the operator will make expenditures on ship main trance. It will also have business expenses in the base or some other country, including costs of operating an office and marketing expenditure, but excluding any marketing costs elsewhere in the world. Further, taxes may be levied on cruise operators. These include income or corporate taxes, but some operators will be exempt, due to the operations of tax agreements and nature of their cruises. There may be customs duties payable, and departure taxes may be levied. It should be noted that apart from direct taxes on cruises, there may be 
indirect taxes, on such items as fuel, and it is possible that government charges for services would include a tax element (Dwyer, Forsyth, 1996; Dwyer, Forsyth, 1998; Figure 1).

Worldwide, employment within the tourism economy is estimated at 192.2 millions jobs. By 2010, this should grow to 251.6 millions jobs (World Travel and Tourism Council, 2000). "...Although tourism is a growth industry and a major creator of value added, the industry is vulnerable to a variety of economic, ecological, geopolitical and meteorological factors, and over-reliance on it can be dangerous for a country" or region. "Economic recession and the impact of natural disaster..." or military attacks can devastate the sector in a country (or in region) for several years. "One example is the war in the Balkans which has seriously reduced tourism income in the area. Events of this kind represent the extremes of a recurrent uncertainty in an industry which is characterized by the seasonal nature of many its activities and by important fluctuations even during normal periods. These factors shape the structure of the tourism labour force, making it difficult to maintain high permanent staffing levels. There is a generic tendency to operate on the basis of a core staff and to employ the labour needed for day-to-day operations under atypical contractual arrangements..." (www.ilo.org/public/english/dialogue/sector/techmeet/tmhct01/tmhct-r.pdf).

The question is: Who is being employed on the cruising along the Pan-European Corridor VII - where the crew come from? As for the country of origin, according to crew manifests from cruisers along the Corridor VII, 32 countries are present, which implies that globalization infiltrated into this segment of tourism. On the first eight positions and on the tenth are citizens of Danube countries, which we assumed even before the research. Moldova is the only Danube country that in our sample did not have a representative in the crews researched. What was not our assumption is the presence of so many nations among the crews. About $99.1 \%$ are citizens of some European country $(2,199$ crew members from 27 different courtiers), $0.1 \%$ come from the USA, while $0.7 \%$ are citizens of one of the three Asian countries (Table 1).

Table 1.

Crew structure according to the country of origin

\begin{tabular}{|c|c|c|c|}
\hline Country & in $\%$ & Country & in $\%$ \\
\hline \multicolumn{2}{|l|}{ Europe } & \multicolumn{2}{|l|}{ Europe } \\
\hline Romania & 24.5 & Norway & $<0.1$ \\
\hline Ukraine & 21.9 & United Kingdom & $<0.1$ \\
\hline Hungary & 14.1 & Belgian & $<0.1$ \\
\hline Slovakia & 13.2 & Denmark & $<0.1$ \\
\hline Bulgaria & 7.2 & Switzerland & $<0.1$ \\
\hline Germany & 6.0 & Slovenia & $<0.1$ \\
\hline Serbia & 4.0 & Italy & $<0.1$ \\
\hline Austria & 2.0 & Portugal & $<0.1$ \\
\hline the Netherlands & 1.2 & Greece & $<0.1$ \\
\hline Croatia & 1.1 & \multicolumn{2}{|c|}{ North America } \\
\hline France & 0.9 & USA & 0.1 \\
\hline the Czech Republic & 0.7 & \multicolumn{2}{|l|}{ Africa } \\
\hline Poland & 0.5 & Ghana & $<0.1$ \\
\hline Bosnia and Herzegovina & 0.4 & \multicolumn{2}{|l|}{ Asia } \\
\hline FYR Macedonia & 0.3 & Indonesia & 0.4 \\
\hline Lithuania & 0.3 & Philippines & 0.2 \\
\hline Russia & 0.2 & Sri Lanka & $<0.1$ \\
\hline Latvia & 0.2 & & \\
\hline
\end{tabular}

\section{Case study: Vojvodina Region}


The tourist turnover is quantitative and qualitative indicator of the supply attractiveness, that is, the recognizability of a particular tourist destination on the market. Tourist turnover is also the result of good promotional appearance of the supplier.

After the bridges on the Danube in Novi Sad were bombed in 1999, the clearance of the Danube basin in that area was commenced by the support of the European Union, the Danube Commission and Corridor VII-Management/TINA Vienna. Two new bridges were built and one pontoon bridge was constructed, with the opening schedule of three times a week to make passage for ships. Thus, the Danube was at least, even with some restrictions, made navigable again as far as to its delta in Romania. On the initiative of the Danube Tourist Commission, passenger ships did not have to pay any toll.

By the year 2004, there was only one harbour in Vojvodina (in Novi Sad) - the "Port of Novi Sad" (on the left bank of the Danube, downstream the pontoon bridge). Following the initiative of the Traffic Office in Novi Sad, the new harbour was opened for tourist vessels "Port of Novi Sad 2" (on the right bank of the Danube, upstream the pontoon bridge). This resulted in direct access of tourist vessels that were cruising downstream from Budapest to Belgrade, and more convenient disembarking of tourists according to the itinerary, without any delays considering the opening schedule of the pontoon bridge.

In October 2005 the third bridge in Novi Sad was reconstructed - "Bridge of Freedom", and the pontoon bridge was finally removed. That meant that navigation on the Danube had been fully restored. Today, there are five piers in Vojvodina Region (four in Novi Sad, and from 2010. one pier in Apatin).

It can be noted that the number of tourists on the Corridor VII (in Vojvodina Region) is increasing every year, with the exception of 2006 and 2008 (Figure 2). The reasons can be found in the extremely high water level of the Danube in April and May 2006, due to which many cruises were, cancelled. For 2008 the reasons can be found in the world financial crisis.

Figure 2.

Total annual number of cruisers (tourists) along the Corridor VII in Vojvodina Region

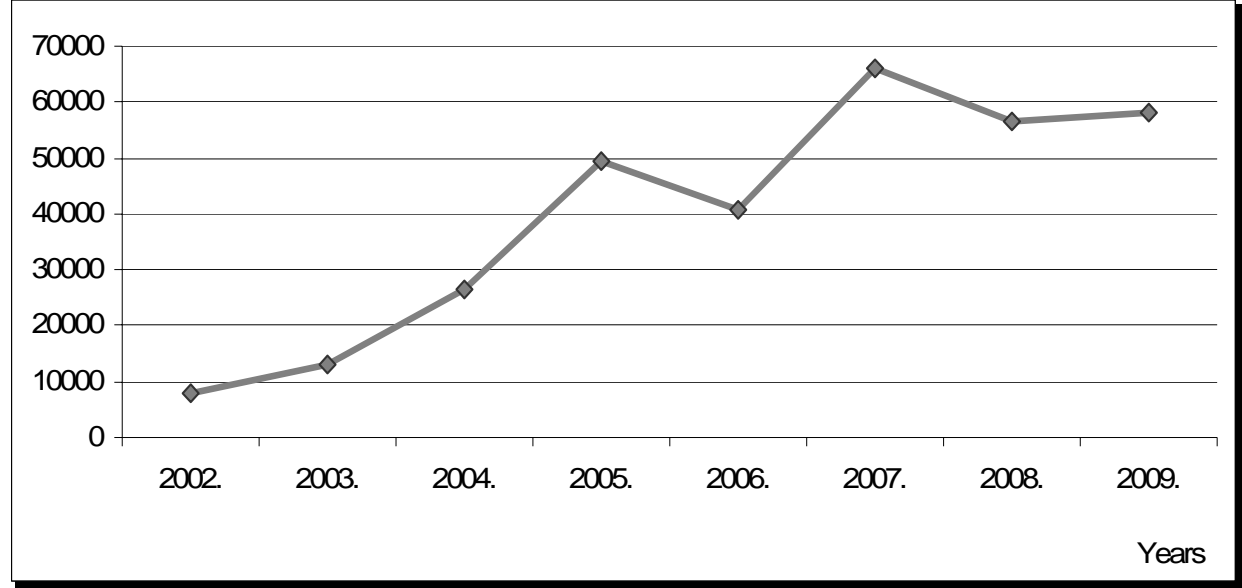

Source: Dragin, 2008; "Novi Sad" Port, 2010

Survey on the quality of services during cruises along the Corridor VII was done in order to comprehend the manners in which tourists experience Vojvodina. The survey has shown that tourists on cruises through Vojvodina are well-travelled persons. Of all the interviewees, $85.7 \%$ said that they decided to go on a cruise along the Corridor VII due to some already gained experience about this form of tourism. However, $90.5 \%$ visited Vojvodina (Serbia) for the first time, so personal experience during the tour was the only factor that helped them shape a picture about this country. 
According to the initial motives, the structure of the tourists is as follows: $26.8 \%$ were attracted by the whole tour; $19.7 \%$ were motivated by the need to visit the countries specified in the itinerary; $18.8 \%$ wanted to get to know the natural treasures of the Danube region and $15.3 \%$ the cultural heritage of the region. In addition, $19.4 \%$ tourists classified their motive as "other" (cruising along the Danube, visits to local villages, home-hosted lunches, scenery of the Balkans, new experience, etc.)

About a third of all tourists thought that they would change/add something in the tour. For example, more information about the visited areas is needed before docking, more activities should be introduced inland, more excursions to rural areas should be offered, more opportunities to meet local communities are needed, etc.

The question of what it is that they liked best in Vojvodina gave rise to the following answers: architecture (24.1\%), nature (17.2\%), folklore $(13.8 \%)$ and hospitality $(13.8 \%)$. In the category "other" $(20.7 \%)$ they put history, culture, friendly people, the banks of the Danube, etc. None of the interviewed tourists selected cuisine or souvenirs, which suggests that the Novi Sad (Vojvodina) supply for the Corridor VII was not adequately designed.

It should be noted that $71.4 \%$ of the interviewed did not have any objections to the Vojvodina (and Serbia) supply. The objections were primarily aimed at insufficient choice of souvenirs, inadequate quality of guidebooks, the pollution of the Danube (rubbish on the banks and floating on water), tiresome walks on the land, etc.

Around $62 \%$ of the interviewed said that the tour through Vojvodina (and Serbia) induced a positive opinion about this region (country), which can be illustrated by the following answers: "One can get the impression that Serbia is prospering and that people look content", "This is a beautiful region", "Novi Sad has an impressive architectural style and cordial people", "It would be nice to visit this region again", etc.

The negative answers (about 35\%) are of the following sort: "The past of Serbia is filled too much with wars", "Novi Sad is on the long way towards the recovery from the wars", "It is difficult to communicate with the local population in English", etc. Nevertheless, all tourists who supplied negative answers would recommend this tour to their friends.

Of all interviewed tourists, $23.1 \%$ did not have a formed opinion about Vojvodina Region or Serbia before the trip. Approximately the same percentage of tourists said that the Corridor VII cruise had a positive effect on changing their view on Vojvodina and Serbia, especially the view upon Serbia's economic development.

The benefits of cruises along the Corridor VII for the Vojvodina Region

Cruises in Vojvodina proceed only along the Corridor VII, that are, along the Danube, and in part along the Tisza and Sava. Given what has been said so far, it follows that the Danube is the axis of international tourist cruises in this area. 


\section{Figure 3.}

\section{Economic impact of cruise tourism along the Pan-European Corridor VII in Vojvodina (effects of tourist promotion and tourist turnover)}

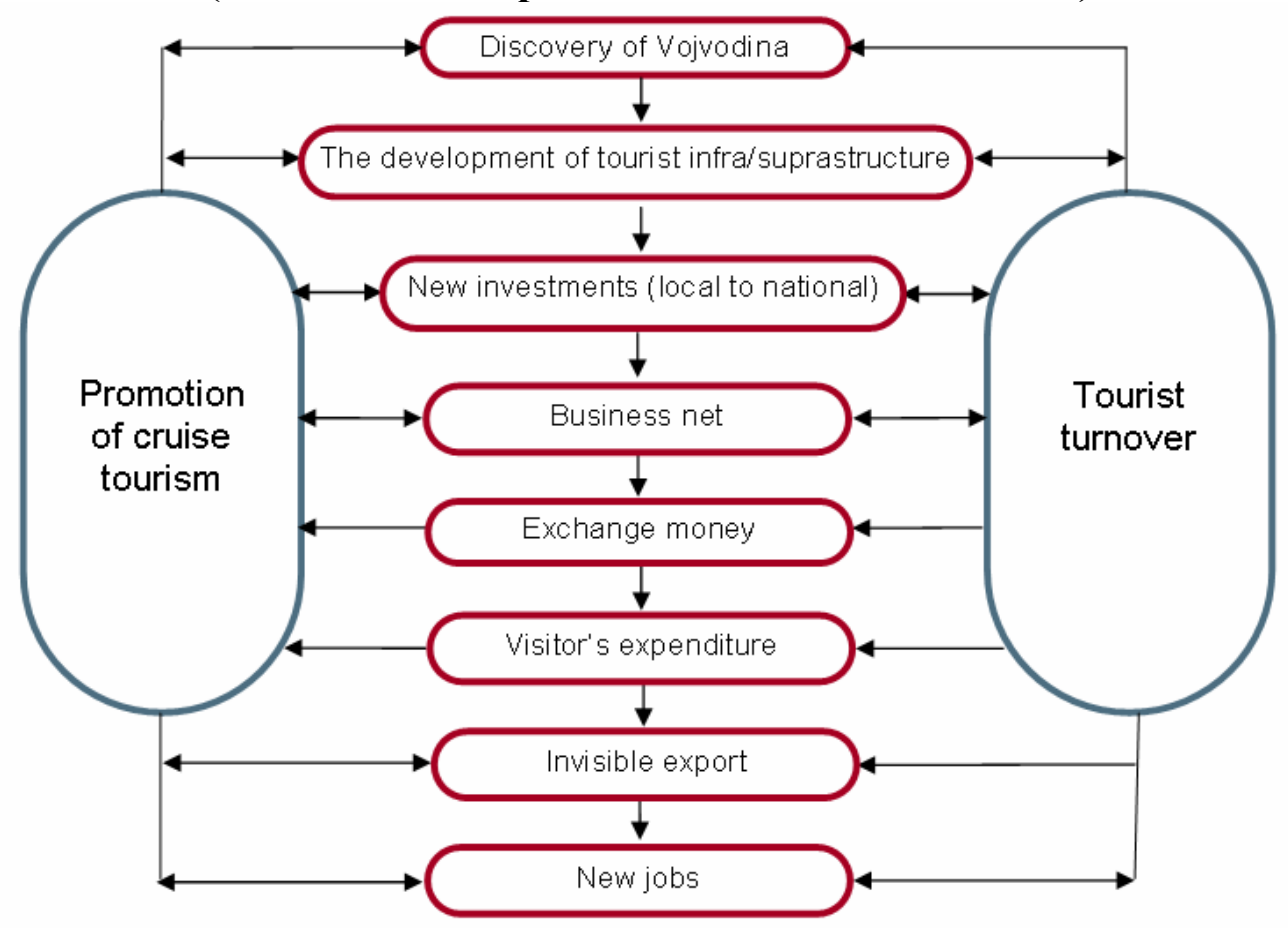

\section{3):}

The benefits of river cruises concerning Vojvodina Province are numerous (Figure

- Discovery of Vojvodina as a tourist destination for potential generating areas at the international tourist market - creation of the image of Vojvodina as an attractive receptive tourist area through the promotion and sale of tourist packages:

o The area abundant in significant natural tourist resources (protected natural values in the Danube riparian area, national parks, etc.), attractive hydrography (canals and smaller rivers); Geo-heritage, etc.);

o Multiethnic and multicultural features (over 24 nations);

o Significant cultural heritage (archaeological sites, medieval fortifications, authentic urban and rural units, etc.).

- Increase in the total tourist turnover in Vojvodina Region. The share of the participants in this form of tourist activities compared to the total foreign tourist turnover in Vojvodina (Statistical Office of the Republic of Serbia, 2003-2009) in 2002 was $15.7 \%$, in 2003 with $27.1 \%$, in 2004 with $46.4 \%$, in 2005 their share reached additional 70.4\%, in 2006 they participated with $52.1 \%$, in 2007 with $67.6 \%$ and in 2008 with $54.2 \%$.

- The development of tourist infrastructure and superstructure (the reconstruction of the quay in Novi Sad is in process, including the parking facilities for tourist buses, and more convenient access for tourists).

- Increase of the total expenditure through foreign tourist payments of various services:

o Ship services - harbouring and tax;

o Issuing passenger permits for stays in border region;

o Shipping transport agencies;

o Fresh drinking water services from the local water supplies in Novi Sad (Public Utility Company "Water Works and Sewerage") and sanitation services for ships 
(Public Utility Company “City Sanitation"). For example daily fresh water demands of a river cruise are approximately $70-100 \mathrm{~m}^{3}$ and daily waste disposal reaches several $\mathrm{m}^{3}$.

o Tourist sojourn tax (the city of Novi Sad);

o Foreign currency exchange in exchange offices and banks;

o Coach transport services (mainly offered by transport companies: "Vojvodina", "Putnik" and "Lasta");

o Sightseeing tours of the city, the Petrovaradin Fortress, Sremski Karlovci, monasteries of Fruška gora, etc. (receptive travel agencies, i.e. "Putnik") and guiding services;

the harbour;

o Evening concerts of folk dance associations during the cruise stay in

o Entrance tickets for various institutions and tourist localities during the sightseeing tour of Novi Sad and its surroundings (the Museum of Vojvodina, the Museum of the town of Novi Sad, etc.) - the growth of the income of tourist localities etc.

- In Vojvodina, links between cruise operators and travel agencies are less well established. With payments from operators, some government charges will be paid directly to the provincial/state/national governments. However, they could have a significant regional component.

- Opening of new job posts - employment possibilities (new harbour, souvenirs production, production of food and drinks of geographical origin, crew, etc.). Due to permanent increase in tourist ships frequency on the Danube, and subsequently the increase in the number of harboured ships in Novi Sad, the function of the Port of Novi Sad 2 did not stop with the removal of the pontoon bridge. The Port was relocated downstream, on the left bank of the Danube, near the centre of Novi Sad in August 2006. From 2008 there are four piers in Novi Sad. Another example of the direct influence of Cruise Ship Tourism on new job opportunities is the opening of the souvenir market near the port for tourist ships in Novi Sad in 2006.

Concerning the Vojvodina Province as a receptive tourism region of the river cruises, there are few shortcomings:

- Whole year season is nine-month. As the weather conditions are making it more difficult and even impossible to travel during winter (low temperatures of air and water, gusts of wind, fog, and particularly the ice on water), it is necessary to come up with an offer that would provide the ships, i.e. the crew, longer working season during the year. This could be achieved by organising Christmas or New Year's Eve programmes in ports.

- There is a need for more information about the visited areas before docking, more activities should be introduced inland, more excursions to rural areas should be offered, more opportunities to meet local communities are needed, etc. (results of the Questionnaire).

- As we already said, additional expenditure per passenger will result if pre or post cruise add-on holidays are taken. But, Vojvodina (Novi Sad) is still not on that list (Novi Sad has not been yet a port before or after cruising).

- Cruise operations are foreign owned, and profits accrue to the owners.

- There is no The National Cruise Shipping Strategy.

\section{THE POLICY IMPLICATIONS}

If we take facts and present situation into account, based on the field research of the Corridor VII cruises and from the perspective of tourist flow, we believe that the analyses introduced in this study are the basis for further material investment in the development characteristic of this matter. 
In many respects, cruise tourism will have an impact on a regional or national economy similar to that of other foreign visitors. They may fly to the county, stay in some accommodation, and purchase goods and services. The difference is that a major component of their expenditure will be on a cruise, and in many cases this payment will be to foreignowned operators who (in turn) will purchase some goods and services in the home region or country (there can be significant tax results, however). Therefore the foreign exchange earnings and the economic impact on the host economy will depend on the visitors direct and indirect expenditure relates to good and services sourced from within the region or sourced from elsewhere. The economic impacts and their distribution will differ also as between the regional and the national economy.

Passengers are foreign. Additional expenditure per passenger will result if pre or post cruise add-on holidays are taken.

Vojvodina region had plenty of positive effects thanks to the tourist flow. These effects were really needed after the 1990's and overall regional crisis (politic, economic, financial and social). Vojvodina Region which used to have a positive tourist image, now disappeared from the pages of tourist brochures.

With the democratic changes in 1999, Vojvodina (Serbia) started its transitional processes, trying to shape its tourist offer as well. Eventually, by creating documents which are concerned with the conception of tourism strategy of the Republic of Serbia (MHCEF, 2005; MHCEF, 2006a; MHCEF, 2006b), it distinguished nine key products, cruises being one of them, representing the path of further tourist interregional integration. In order for cruises along the Corridor VII to provide prosperity in the forthcoming period, it is necessary that this form of tourism be integrated into plans and programmes of tourism development of the entire Corridor VII. However, without adequate plans for nautical tourism, the reconstruction of the existing and new infrastructure and increase in service quality, it is reasonable to expect a decline in the competitiveness of the Vojvodina's supply at the international cruise tourism market. In this manner, positive effects of the entire tourism economy will be diminished.

Cruisers are definitely a good employment market, which is particularly useful for the majority of the Danube countries which changed from the socialist to capitalistic system in the last decade of the $20^{\text {th }}$ century and which are still in the stage of transition. The employment market in the developed Danube countries is equally important bearing in mind the world financial crisis of the last couple of years. It must be pointed out that the crisis is the very reason why cruise companies have been reducing their budget, while the same companies expect at least equal results as in the previous seasons.

The advantages of cruises include: the content of the supply/tour, comfort, and safety. Given these advantages, further development of the competitiveness of cruising tours along the Corridor VII requires specific measures, such as a more intensive promotional appearance at international markets, enhanced investment in attractive localities, distribution of domestic products to foreign visitors (souvenirs, food products) on ships or to localities in itineraries, etc.

Disadvantages or delimiting factors for a more successful market competitive of cruises along the Vojvodina section of the Corridor VII include: underdeveloped infra and suprastructure (traffic signalization, exchange offices, parking lots, restaurants, bars), little time spent at itinerary destinations (the average duration of a stay on a tour of Novi Sad is 3-5 hours), etc. It is necessary to activate attractive localities which are not included in itineraries of Corridor VII cruises although they are situated on the navigation path.

At the social and economic level, important are the effects related to increased employment in various tourism-related sectors and a favourable climate for attracting domestic and foreign investors. A great significance is given to the effects that lead to the strengthening of regional tourism integrations via the Corridor VII, as well as to connecting 
cultures of different ethnic communities, the representatives of which are both tourists on cruises and tour providers.

The realization of tours along the Corridor VII requires opening new job positions. However, sometimes new posts are opened indirectly, not only for the purpose of satisfying the needs of cruise companies. Such is the case with the opening of a souvenir market in Novi Sad where souvenirs created by local artists are exhibited to tourists docking from a ship.

In order for cruises along the Corridor VII to provide prosperity in the forthcoming period, it is necessary that this form of tourism be integrated into plans and programmes of tourism development of the entire Corridor VII and Serbia as a whole. However, without adequate plans for nautical tourism, the reconstruction of the existing and new infrastructure and increase in service quality, it is reasonable to expect a decline in the competitiveness of the Vojvodina's supply at the international cruise tourism market. In this manner, positive effects of the entire tourism economy will be diminished.

Of all the interviewees, $85.7 \%$ cruisers said that they decided to go on a cruise along the Corridor VII due to some already gained experience about this form of tourism. However, 90.5\% visited Vojvodina (Serbia) for the first time, so personal experience during the tour was the only factor that helped them shape a picture about this country. Wirth a good service, tourists become more satisfied and the positive image is thus spread among potential future tourists and they become familiar with that sort of travel, specific cruise company and cruise destination.

It has been said that, bearing in mind the demographic profile of the tourist on cruisers (older, educated and well off), the employees must have skills that underpin customer service relationships or interpersonal communications (Gibson, 2008).

To sum up the affirmation of this topic was encouraged by numerous facts that refer to unquestionably multi-effective impact that international cruises have upon receptive countries / regions and consist of the following: activation of tourist offer in receptive areas and spreading of the positive image, development of different economic activities, employment possibilities in different sectors, creation of favourable atmosphere for domestic and foreign investors, effects of regional tourist integration along Corridor VII, cultural integration of nations etc.

We can therefore conclude that cruises along the Corridor VII can contribute to the promotion of the Danube region in Serbia, in particular, the promotion of specific centres and localities, to a greater extent than used to be the case up to now. This means that cruise tourism can function as a strong impetus for reviving those regions in Serbia that during the past two decades went through the process of transition - social, political and economic (most of the Danube countries).

\section{ACKNOWLEDGEMENTS}

The research that is presented here is part of the project approved by the Ministry of Science of the Republic of Serbia (Demographic Transition in Serbia - No. 146017d) and also a part of the doctoral dissertation defended by Aleksandra Dragin at the University of Novi Sad in 2008.

The research part was accomplished with the help of the following cruise line companies: "Grand Circle Travel", "Vantage Delux World Travel", "Croisi Europe“, "Viking River Cruises", "Avalon Waterways", "Phoenix Reisen Gmbh" and other. Great supports were ship captains, especially Frank Versluis and Pavol Buzgovič. We express immense gratitude for valuable information to the director of Port authority "Novi Sad", Mr. Boris Oreb, personnel of the Pier "Novi Sad", Port of Belgrade, "Border police Novi Sad" (Port of Novi Sad) and personnel of the Pier "Novi Sad 2" (Public Communal Enterprise "Gradsko 
zelenilo", Novi Sad), especially Vojislav Dragin, Jovan Stanisavljević, Zlatko Grabež and Branimir Lazić. The authors also would like to thank the cruise line employees who also participated in the interviews for their valuable time, as well as all other employees of the cruise company, especially Nikola Vuksanović ("Grand Circle Travel") and Prof Gerhard Skoff (president of the "Danube Tourist Commission").

\section{REFERENCES}

Armenski,T., Zakić,L., Dragin,A.S. (2009), "Building Up the Destination Image - Case Study of Event, City-Break and Cruising Tourism in Serbia”, Glasnik srpskog geografskog društva, 89 (1):39-63.

Braun,B., Xander,J., White,K. (2002), "The impact of the cruise industry on a region"s economy: a case study of Port Canaveral, Florida". Tourism Economics, 8:281-288.

Brida,J.G., Aguire,S.Z. (2008), The Impacts of the Cruise Industry on Tourism Destinations, (Milano: University of Milano Bicocca, Research Unit on Sustainable Development).

Chase,G., Alon,I. (2002), "Evaluating the economic impact of cruise tourism: a case study of Barbados". Anatolia: An International Journal of Tourism and Hospitality Research, 13 (1):5-18.

Cruise Lines International Association (CLIA) (1992). The Cruise Industry: An Overview, (New York: Cruise Line International Association).

CLIA (1995), The Cruise Industry: An Overview. Marketing Edition, (New York: Cruise Line International Association).

CLIA (2005a), CLIA celebrates 3o years of excellence with ambitious growth and marketing agenda, Cruise Line International Association News Releas, 2 August (preuzeto sa www.cruising.org).

CLIA (2005b), A future bright with promise, Cruise Line International Association News Releas, May (preuzeto sa www.cruising.org).

CLIA (2006a), The overview 2006, (Fort Lauderdale: Cruise Line International Association).

CLIA (2006b), Cruise industry overview. Retrieved January 2010, from: /http://www.cruising.org/press/overview\%202006/ind_overview.cfmS.

Cruise Information Service. 2005. Annual Cruise Review 2004 (UK and Europe), December 2006. www.discover-cruise.co.uk

Dowling,R.K. (2006), Cruise Ship Tourism, (CABI, Oxfordshire).

Dragin,A.S. (2008), Međunarodna krstarenja Koridorom 7 i nautički turizam Srbije, (Unpublished doctoral dissertation), (Novi Sad: University of Novi Sad).

Dragin,A. (2010), Međunarodna turistička krstarenja Koridorom 7, (Novi Sad: Univerzitet u Novom Sadu, Prirodno-matematički fakultet, Departman za geografiju, turizam i hotelijerstvo).

Dragin,A., Bubalo-Živkovic,M., Ivanović,Lj. (2009), “The Romanians on international cruises along the Corridor VII: The structure of the crew on tourist boats", Geographica Timisiensis, 1-2:35- 44.

Dragin,A., Ivkov,A., Dragin,V. (2006), "Nautical Tourism as Development Potential of the Danube Countries in South Eastern Europe", Danubius Pannonico Mysicus, Space of Challenges, University of Novi Sad, Faculty of Natural Science and Mathematics, Department of Geography, Tourism and Hotel Management, Novi Sad, page 28.

Dragin,A.S., Dragin,V., Plavša,J., Ivkov,A., Djurdjev,B.S. (2007), "Cruise Ship Tourism on the Danube in Vojvodina Province as a Segment of Global Tourism", Geographica Pannonica, 11:59-64. 
Dragin,A.S., Đurđev,B.S., Armenski,T. (2008), "Da li su međunarodna turistička krstarenja Pan-evropskim Koridorom 7 zaista putovanja turista treće dobi?" Glasnik srpskog geografskog društva, 88 (4):29-38.

Dragin,V., Ivkov,A., Maletin (Dragin),A. (2004), "Cruising Voyages Along the Danube as a Form of Contemporary Tendencies of Global Touristic Movements", Tourism 8:19-21.

Dwyer,L., Forsyth,P. (1996), "Economic impacts of cruise tourism in Australia", Journal of Tourism Studies, 7:36-43.

Dwyer,L., Forsyth,P. (1998), "Economic significance of cruise tourism", Annals of Tourism Research, 25 (2):393-415.

Foster,G.M. (1986), "South Seas Cruise: A Case Study of A Short-lived Society", Annals of Tourism Research, 13:215-238.

Gibson,P. (2006), Cruise Operations Management, (Burlington: Butterworth Heinemann).

Gibson,P. (2008), "Cruising in the 21st century: Who works while others play?" International Journal of Hospitality Management, 27 (1):42-52.

Hall,A.J., Braithwaite,R. (1990), “Caribbean Cruise Tourism: A Business of Transnational Partnerships”, Tourism Management, 11:339-347.

Henthorne,T.L. (2000), "An analysis of expenditures by cruise ship passengers in Jamaica", Journal of Travel Research, 38:246-250.

Hobson,J., Perry.S. (1993), “Analysis of the US cruise line industry”, Tourism Management, December:452-462.

Hung,K., Petrick,J.F. (2010), "Developing a measurement scale for constraints to cruising", Annal of Tourism Research, 37 (1):206-228.

Ivkov,A., Kovačević,T., Dragin,A., Djurdjev,B., Ivanović,Lj. (2007), "Influence of tourism on the employment in Vojvodina", Geographica Pannonica, 11:54-58.

$\mathrm{Li}, \mathrm{X}$. (2006), Examining the antecedents and structure of customer loyalty in a tourism context, (Unpublished dissertation), (Texas A\&M University, College Station).

Mancini,M. (2000), Cruising a Guide to the Cruise Line Industry, (Albany, NY Delmar).

Marti,B., E. (2004), "Trends in world and extended-length cruising (1985-2002)", Marine Policy 28:199-211.

Mescon,T., Vosikis,G. (1985), "Economic Impact of Tourism at the Port of Miami", Annals of Tourism Research, 12:515-528.

Ministarstvo trgovine, turizma i usluga Republike Srbije, Horwath Consulting Zagreb i Ekonomski fakultet Beograd (MHCEF) (2005), Strategija turizma Republike Srbije - Prvi fazni izveštaj, (Beograd: Ministarstvo trgovine, turizma i usluga Republike Srbije).

MHCEF (2006a), Strategija turizma Republike Srbije - Drugi izveštaj, Strateški marketing plan, (Beograd: Ministarstvo trgovine, turizma i usluga Republike Srbije).

MHCEF (2006b), Strategija turizma Republike Srbije - Drugi izveštaj, Plan konkurentnosti, (Beograd: Ministarstvo trgovine, turizma i usluga Republike Srbije).

Peisley,T. (1992), "The world cruise ship industry in the 1990's", Special Report No. 2104. London: Economist Intelligence Unit.

Peisley,T. (2006), The Future of Cruising - Boom or Bust, (Colchester: Seatrade Research Report).

Petrick,J.F. (2003), "Measuring cruise passengers" perceived value", Tourism Analysis, 7 (34):251-258.

Petrick,J.F. (2004), "The role of quality, value, and satisfaction in predicting cruise passengers" behavioral intentions", Journal of Travel Research, 42:397-407.

Petrick,J.F., Sirakaya,E. (2004), "Segmenting cruisers by loyalty", Annals of Tourism Research 31 (2):172-173.

Statistical Office of the Republic of Serbia (2003-2009), Statistical Yearbook of Serbia, (Belgrade: Republic Printing Office). 
Ward,D. (2005), Complete Guide to Cruising and Cruise Ships 2004, (London: Berlitz Publishing).

World Tourism Organization (2003), "Worldwide Cruise Ship Activity", (Madrid: World Tourism Organization), preuzeto od Dowling, 2006.

Data of the "Novi Sad" Port

www.ilo.org/public/english/dialogue/sector/techmeet/tmhet01/tmhct-r.pdf

www.tinavienna.at/service/upload/MoU.pdf

\title{
KRSTARENJA PAN-EUROPSKIM KORIDOROM VII I NJIHOV EKONOMSKI ZNAČAJ NA RECEPTIVNE PROSTORE
}

\begin{abstract}
SA
Ovim radom su analizirana međunarodna turistička krstarenja Pan-europskim Koridorom VII, odnosno njihov utjecaj (potencijalne dobrobiti) na ekonomiju receptivnih prostora. Studijom slučaja (Vojvodina) dati su primjeri koji to ilustriraju.

Rezultati analize pokazuju da kruzevi Koridorom VII utječu pozitivno na Vojvodinu, prvenstveno na priobalnu, podunavsku regiju i to u Novom Sadu (gdje brodovi pristaju). Iako se beneficije ne odnose na korištenje usluga smještaja i hrane na kopnu, dobrobit se ogleda u sljedećim segmentima: turistička promocija (širenje pozitivnog plasmana Vojvodine kao receptivnog prostora na inozemnom tržištu - predstavljanje kulturne baštine $i$ prirodnih vrijednosti); porast inozemnog turističkog prometa, a samim tim i potrošnje posjetilaca; otvaranje novih radnih mjesta (adekvatna infrastruktura i suprastruktura - serviseri različitih usluga brodovima, posadi i putnicima) - pristaništa, špediteri, suvenir tržnice $i$ dr. / novi proizvodi, širenje poslovne mreže, promjena valute, nevidljivi izvoz itd.

Rezultati istraživanja mogu pomoći daljim proučavanjima uzročno-posljedičnih veza između ovakvog vida putovanja i resursa receptivnih zemalja na kojima se ova putovanja događaju, a sve u cilju adekvatnog osmišljavanja i plasmana turističke ponude, odnosno optimalnog razvoja receptivnih zemalja kroz održivi turizam. Rad pruža i informacije različitim partnerima (,stakeholders") uključenim u turističko privređivanje kruzeva, koji očekuju privatnu i društvenu dobit od svojih ulaganja.
\end{abstract}

Ključne riječi: turizam, kruzevi, Dunav, Vojvodina, Srbija, tranzicija, ekonomski značaj, demografija 